Georgetown University Institutional Repository http://www.library.georgetown.edu/digitalgeorgetown

The author made this article openly available online. Please tell us how this access affects you. Your story matters.

OSGOOD, J. 'Eloquence under the Triumvirs' The American Journal of Philology, Vol. 127, No. 4 (Winter, 2006), pp. 525-551

Collection Permanent Link: http://hdl.handle.net/10822/555439

(C) 2006 The Johns Hopkins University Press

This material is made available online with the permission of the author, and in accordance with publisher policies. No further reproduction or distribution of this copy is permitted by electronic transmission or any other means. 


\title{
ELOQUENCE UNDER THE TRIUMVIRS
}

\author{
JOSIAH OSGOOD
}

\begin{abstract}
$\infty$
Nec ullus Asinii aut Messallae liber tam inlustris est quam Medea Ovidii aut Varii Thyestes.
\end{abstract}

—Tacitus, Dialogus 12.6

Editus hic ego sum, nec non, ut tempora noris, cum cecidit fato consul uterque pari.

-Ovid, Tristia 4.10.5-6

\begin{abstract}
This paper explores oratory at Rome after the death of Caesar. It examines the three main sources for the period, Plutarch, Appian, and Dio, who suggest that an outspoken oratory on affairs of state was no longer possible, and then less familiar sources, which reveal that speeches still were made, sometimes concerning affairs of state. Though it was difficult to criticize the triumvirs (as the few known efforts at protest show), aspiring orators managed to showcase talent and display doctrina and diligentia, if not libertas. Oratory did not so much decline in the triumviral period as adapt to new circumstances.
\end{abstract}

FOR ALL THEIR TURBULENCE, the fifteen years between the death of Cicero and the Senate meeting of 13 January 27 B.C.E., when Imperator Caesar Divi filius acquired the additional name Augustus, witnessed, as Ronald Syme $(1964,274-75)$ remarked, "a remarkable flowering" of literature at Rome that included many "novel types of writing." 1 During this time, Vergil crafted the first pastorals in Latin, a fascinating mixture of Theocritean translation and references to contemporary politics, and then went on to produce the equally complex Georgics. His friend Horace revived Lucilian satire but with a verse style totally new; and he also created in Latin the first book of iambs in the style of Archilochus,

${ }^{1}$ Syme's notion of a "triumviral period" of Latin literature was subsequently developed in Syme 1978, 169-79, and Syme 1986, 12. I owe the title of this paper to Syme 1986, 206. Osgood 2006 elaborates Syme's idea but, in focusing on extant works of triumviral literature, has less discussion of oratory, my subject here. All translations of Greek and Latin are my own. 
though again, references to the ongoing struggle for power appear at key moments in the collection. By 28, Propertius had finished his Cynthia, with its haunting pair of final poems, while numerous other works of poetry - the Thyestes of Varius, for instance-have disappeared. ${ }^{2}$ Meanwhile, Sallust fashioned his innovative monographs and then began work on the Histories, the latter more conventional in form but still parading his bold new prose style. Asinius Pollio also wrote a history, which took as its starting place the year 60 B.C.E., and so offered one of the first (and most influential) treatments of the recent civil wars. ${ }^{3}$ Varro, Atticus, and Cornelius Nepos, survivors from an earlier period, kept working, though their works, too, do not lack novelty. Nepos' "Life of Atticus," for instance, unusually took as its subject a living contemporary, who was praised above all else for protecting his friends during the proscriptions. ${ }^{4}$

The conspicuous absence in this canon of triumviral masterpieces, especially when one thinks of the period that came before, is the title of an important work of oratory. Despite Cicero's complaints about the fate of public speaking under the dictatorship of Caesar, after the Ides, Romans again, for a time, witnessed a sometimes open, even fiery, debate on the day's political issues. Speeches made in the Senate-for instance those on the seventeenth of March that recommended amnesty for the assassins of Caesar or those at the start of January, 43 B.C.E., when Octavian was voted imperium - determined the direction history took. Most notable in this revival were Cicero's own Philippics. But the Philippics, along with Cicero's letters, make clear how many other speeches of consequence

${ }^{2}$ Publication of Propertius' Cynthia is to be dated to the very end of 29 or early 28 B.C.E.; 2.31 refers to the dedication of the Temple of Apollo on the Palatine, which occurred in October 28. The book is addressed to L. Volcacius Tullus, who left for Asia in 30 or 29. See, e.g., Syme 1978, 98.

${ }^{3}$ The starting date is given by Hor. Odes 2.1 .1 ("civil disturbance from the consulship of Metellus" [motum ex Metello consule civicum]), where Metellus is taken to be Q. Caecilius Metellus Celer, the consul of 60 B.C.E. Woodman 2003, 203-11 suggests that there is a reference in Horace's Metello to the consul of 109 B.C.E., and that Pollio's history had a Pentekontaetia that started in this earlier year. But the apparent references to the so-called 'first triumvirate' in Horace's first two stanzas, "the dangerous friendships of leading men" and "an undertaking full of perilous risk" (gravis . . / principum amicitias and periculosae plenum opus aleae) support the standard interpretation.

${ }^{4}$ Chapters 1-18 are generally taken to have been written and published in Atticus' own lifetime, chapters 19-22 afterwards, since chapter 19 begins with the words "this much was related by me when Atticus was still alive" (hactenus Attico vivo edita a nobis sunt). For a different interpretation, arguing that chapters 1-18, together with 19-22, appeared only after Atticus' death, see Toher 2002. 
were given, in the Senate and the Forum, by Antony and also such men as Hirtius, Pansa, Dolabella, and Cicero's bête noire, Fufius Calenus. ${ }^{5}$ Brutus, meanwhile, though he had fled Rome, prepared for distribution the oration he had given on the Capitoline two days after the assassination. ${ }^{6}$ Passionately concerned with the future, these speeches also spent time reflecting on the late Caesar. In the months after the Ides, that was an all-important theme. Even as he fought in the renewed civil war, Hirtius labored to complete Caesar's commentaries, while Oppius and Balbus may have begun their own accounts of the dictator. ${ }^{7}$

Yet in the years immediately following the creation of the triumvirate (by the lex Titia, passed in the Plebeian Assembly on 27 November 43 B.C.E.), the record for public speeches at Rome-in the Senate, before the people, or in the law courts-changes significantly. We hear very little of the heated exchanges among senators or of the political feuding in the courts that took place in the decades before. The reason is, presumably, obvious. Under the autocracy of the triumvirs, Syme argues, "the pursuit of oratory, interrupted by civil war, languished and declined ... with no use left in the Senate or Forum, but only of service to overcome the recalcitrance of armed men or allay the suspicions of political negotiators in secret conclave." 8

While not wishing to minimize the dangers an autocratic government can pose to freedom of expression, I will argue in this article that the straightforward notion of "decline" articulated by Syme, which echoes views to be found in ancient authors such as Tacitus, needs modification. There is evidence, more than is generally realized, for the continued existence of oratory under the triumvirate: speeches were not just made before "armed men" or "in secret conclave." "Gathering together this evidence, I show that, while there was indeed less scope for an outspoken oratory (an oratory

${ }^{5}$ Antony: Phil. 1.8, 2.1 etc., 3.27, 5.19; Hirtius: see Phil. 5.1; Pansa: see Phil. 5.1, 9.3, 10.1-2; Fam. 12.7.1; Fufius Calenus: Phil. 5.1, 4, 8.11, 10.3, 5, 12.3 etc. For further details on these orators, see Malcovati $O R F^{4}$ nos. 159 (Antony), 161 (Hirtius), and 160 (Pansa); Fufius Calenus is not included.

${ }^{6}$ Cic. Att. 15.1.2, 15.3.2; Plut. Brut. 18.10. For the day of delivery (given by Malcovati ORF 467 as 16 March), see Motzo 1940.

${ }^{7}$ Hirtius: $B G 8.1$ and Suet. Iul. 56.1. Oppius and Balbus: see the evidence gathered at Peter $H R R$ 2.lxi-lxiii and 46-49.

${ }^{8}$ Syme 1939, 245; cf. 483. Cf. also Morgan 2000, 65.

${ }^{9}$ The triumviral period is here defined as lasting from November 43 B.C.E. to the end of 32 B.C.E., when war was declared on Cleopatra. But for the controversy surrounding the date on which the triumvirate itself legally expired, see $n$. 55 below. 
marked by libertas $)^{10}$ that addressed affairs of state (e.g., the assignment of commands or the maladministration of provinces), speakers still found opportunities to speak in the Senate and before the People. They spoke on affairs of state and also in the courts, and made efforts to achieve something that could be deemed eloquentia. A period of great creativity in various types of literature, the triumviral years led oratory in new directions and (we can see in retrospect) were a transition to the principate. ${ }^{11}$

Our three main sources for triumviral history all wrote in Greek more than one hundred, even two hundred, years after the events in question. Nonetheless, Plutarch, Appian, and Cassius Dio, when read together, give a relatively full account of the late 40 s and 30 s B.C.E. ${ }^{12}$ It is certainly more detailed than what we have, e.g., for the later Augustan period. Given this amount of detail, it is significant that these authors say so little about important speeches on political affairs delivered before the Senate, at meetings of the people, or in law courts during the triumviral period. This silence is all the more striking because Dio in particular does pay some attention to the role of oratory in the late Republic. ${ }^{13}$

The speeches these authors do mention are very few indeed, and all are given by the major historical figures themselves. The two most important addresses they refer to, each discussed by both Appian and Dio, were (1) that spoken by Lucius Antonius, as consul, in 41 B.C.E. at the onset of the Perusine War, and (2) that of Octavian in 36 B.C.E., after the defeat of Sextus Pompey at the battle of Naulochus. Lucius Antonius, according to Appian (B.Civ. 5.30-31), in his speech to the people in 41 B.C.E. denounced Octavian and Lepidus and promised that his brother was prepared to resign from the triumvirate and serve as a consul in a newly restored republic. ${ }^{14}$ Octavian, according to Dio (49.15.3), assembled the people in 36 B.C.E. and, harking back to an old custom, addressed

${ }^{10}$ For examples of libertas as "outspokenness" see $O L D$ s.v. libertas 7 and $T L L$ s.v. libertas 1314.28-80.

${ }^{11}$ The standard history of Roman oratory in English, Kennedy 1972, like other literary histories, makes too clean a break between the age of Cicero and Augustan Rome (the subjects of chapters 3 and 4 respectively).

${ }^{12}$ For analysis of Appian and Dio, see especially Gowing 1992a. For Plutarch's Antony, see especially Pelling 1988.

${ }^{13}$ See, e.g., 36.20-36, 36.42-44.2, 37.36, 37.49-50, 38.4-5, 39.9, 39.33-36, 39.62-63, and 40.61. It is worth noting how important a role Dio's testimony plays in Millar 1998.

${ }^{14}$ Dio's notice is at 48.13.5. 
them outside the pomerium. ${ }^{15} \mathrm{He}$ spoke of his military exploits, and he included, Appian says (B.Civ. 5.130), a justification of his career up until that point; he also made a speech to the Senate. Copies of these orations were written down and released to the public, Appian also says, and these may be the ultimate source for the historians' information. It is not impossible that a copy of Lucius Antonius' speech denouncing Octavian survived too.

Otherwise, with the notable exception of several speeches made in 32 , to be discussed below, the other orations referred to are more shadowy. In 41 B.C.E., Appian tells us (B.Civ. 5.32), the triumvirs spoke to the people on the issue of taxation, but whether it was Lepidus or Octavian, or both, we are not told. In the later 30s, Plutarch (Ant. 55.1) and Dio (50.2.1) note, Octavian made various denunciations of Antony to both the Senate and the people. These later speeches would have been remembered by historians such as Livy, as they wrote the history of the triumviral period; they also may have been referred to by Augustus in the autobiography he wrote in the $20 \mathrm{~s}$.

In addition, then, to suggesting that there was less by way of freespoken political oratory in the triumviral period than there had been before, Plutarch, Appian, and Dio give an impression of the oratory that did exist. It was, as Syme argues, not part of any deliberative process, as it had been in the late Republican Senate and Forum, or even in 44 and 43 B.C.E. To be sure, even in Republican times public debate was significantly constrained by a variety of factors (e.g., the order of precedence established at senatorial meetings, the ties of obligation that bound younger politicians to old, the rules that prevailed at contiones), and the views of the maximi viri were especially influential. ${ }^{16}$ The ruling class of Rome did not generally believe that staging a full and open discussion of public affairs was desirable. ${ }^{17}$ Thus, we should not think that Rome

${ }^{15}$ Contiones outside the pomerium were held, in Republican times, in the Circus Flaminius, and allowed generals awaiting a triumph to address the people. See especially Taylor 1966, 20-21. Octavian, who would receive only an ovatio for his victory over Sextus Pompey, presumably spoke in this venue in 36 to underscore the message that the irregularities of recent times were subsiding. In 9 B.C.E., Taylor 1966, 119 n. 13 notes, Augustus, after just returning from a campaign, refrained from crossing the pomerium when he spoke the Elder Drusus' funeral oration. (The evidence is Dio 55.2.2.)

${ }^{16}$ Much of this sentence derives from comments made to me by an anonymous reader for the journal. On limits on freedom of speech, see Wirszubski 1950, 18 and 20-21.

${ }^{17}$ Morstein-Marx 2004, esp. 160-203 argues strongly for the lack of debate (in the sense of "reasonably full and fair discussion of alternative courses of action") at contiones, those occasions where (unlike meetings of the Senate) Roman magistrates spoke before the populus Romanus. 
went from total libertas to none; rather, the creation of the triumvirate established a type of government in which libertas was limited differently. The maximi viri had shrunk to three in number, and its members tended to settle their differences privately. Because of the great power of the maximi viri, it was risky for others to deviate far from their views in public. Lucius Antonius and his denunciation may be something of an exception, although historians have rightly wondered just how sincere his Republicanism was. ${ }^{18}$ And in any case, Lucius Antonius' unsuccessful struggle, culminating in the grim siege at Perusia, suggested the real futility of attacks, whatever their motives, on the rulers of Italy.

Having examined the impression left by the three main sources, the investigation now turns to the evidence for triumviral oratory that can be gathered from other sources. This material, which comes from contemporary inscriptions, Latin authors such as the Elder Seneca and Quintilian, and the writings of Josephus, suggests that Plutarch, Dio, and Appian are almost certainly correct in envisioning a dearth of any kind of debate concerning important political matters. Nonetheless, this material also shows that there were occasions for aspiring orators to speak. It will be easiest first to summarize the evidence for known orations and then in a subsequent section of the article explore its implications.

1. Early (it would seem) in the triumviral period, Asinius Pollio defended in court L. Aelius Lamia and subsequently distributed a copy of the speech which included the allegation that Cicero, on the eve of his death, had promised Antony he would recant all of his criticisms of the triumvir and produce speeches "opposite to those, many times more in number, and more carefully written" and that he would "recite them himself at a public meeting." ${ }^{19}$ Seneca the Elder, who preserves Pollio's allegation, is sure that

${ }^{18}$ Appian maintains that Lucius Antonius took up the cause of the dispossessed farmers after the land confiscations of 41 B.C.E. because he was genuinely a Republican and an opponent of the triumvirs (see esp. B.Civ. 5.19); Dio depicts him acting solely out of a desire to gain power. While Dio's version seems ultimately to derive from the (distorted) version of events given in Octavian's autobiography, Appian's Lucius Antonius is an idealized figure who corresponds to the other eloquent critics of the triumvirs we find in the Civil Wars (Cassius and Hortensia especially). Discussions of this problem include Syme 1939, $208 \mathrm{n}$. 1, Gabba 1956, 192-93, Sordi 1985, Roddaz 1988, and Gowing 1992a, 78-84.

${ }^{19}$ Sen. Suas. 6.15 ("he promised to produce speeches opposite to those, many times more in number, and more carefully written, and even to recite them himself openly at a 
the charge is false since Pollio did not reproduce it in his history or even make it, according to eyewitnesses, in the spoken version of the speech, "since he was not able to lie when the triumvirs, aware of their guilt, were around" (nec enim mentiri sub triumvirorum conscientia sustinebat). $\mathrm{He}$ only placed it in the later, published version of the Pro Lamia.

2. Towards the very end of 40 B.C.E. Herod, the son of Antipater of Idumea, arrived in Rome to seek recognition in his struggle against the usurper Antigonus. After he met with Antony (Josephus writes in his Jewish War), that triumvir "determined even then to appoint him king of the Jews" (1.282). Octavian approved too. "And so," we read in the Jewish Antiquities, which tells basically the same story, "Messalla and Atratinus after him convened the Senate" and gave speeches dwelling on Antipater's good deeds, Herod's loyalty to the Romans, and the wrongdoings of Antigonus (14.384). The Senate was "provoked" and then heard a speech of Antony, who said that it would help in his war against the Parthians to have Herod as king; "and as this proposal was acceptable to all, they voted accordingly" (14.385). The newly named king went with Antony, Octavian, and the other senators to the Capitol, where they made sacrifice and deposited a copy of the decree..$^{20}$ From Josephus, then, we learn of three speeches made by Antony, by the former Republican and patrician, M. Valerius Messalla Corvinus, and by the strong Antonian L. Sempronius Atratinus, who is familiar to students of Latin literature for his (unsuccessful) prosecution of Caelius Rufus in 56 B.C.E. ${ }^{21}$

3. Another speech of Messalla delivered in the triumviral period may also be known. Quintilian twice in his Orator's Education mentions a (still extant) speech this patrician delivered in court against one Aufidia,

\footnotetext{
public meeting" ["multiplicesque numero et accuratius scriptas illis contrarias edere ac vel ipse palam pro contione recitare pollicebatur"]). The trial should have taken place, then, between 7 December 43 and the following summer, when Antony and Octavian left Italy for the Philippi campaign. For further speculations on the trial, see Treggiari 1973, 249-51. Malcovati $O R F^{4}$ no. 174 gives full details of Pollio's oratorical career; see also André 1949, 67-79 and Haller 1967, 85-90.

${ }^{20}$ Josephus envisions the Senate decree as deposited on the Capitol, whereas the normal place would have been the aerarium Saturni below (cf., e.g., Jos. AJ 12.219). Some decrees were displayed in bronze on the Capitol (see Jos. $A J 14.188$ and Suet. Vesp. 8.5, who notes "senate decrees, plebiscites concerning alliances, treaties, and privileges granted to anyone" ["senatus consulta, plebi scita de societate et foedere ac privilegio cuicumque concessis"]), and this may have been one such instance-or so Josephus thinks, at any rate. Cf. the decretum for King Deiotarus of Galatia envisioned by Cicero as in Capitolio fixum (Phil. 2.93).

${ }^{21}$ On the career of Atratinus, see Austin 1960,154-55. On Atratinus as orator, see Malcovati $O R F^{4}$ no. 171; on Messalla, $O R F^{4}$ no. 176.
} 
apparently in an inheritance case. ${ }^{22}$ The professor of rhetoric recommends study of it, along with the defense speech of Servius Sulpicius; the latter contained an intriguing line which Quintilian quotes: "Am I to think you were drowsy with sleep, or weighed down by some heavy lethargy?" (somnone te languidum an gravi lethargo putem pressum?). ${ }^{23}$ Quintilian altogether makes thirteen mentions of a Servius or Servius Sulpicius, and these were all taken to refer to the great jurist and consul of 51 B.C.E., who died in January 43 B.C.E. and received a eulogy in Cicero's ninth Philippic. ${ }^{24}$ In an ingenious article, Syme showed that a number of these passages can be made to refer to the jurist only with great difficulty, and are far likelier to refer to the jurist's son (who himself was father of the poet Sulpicia); from these passages the younger Servius emerges as a skilled orator who took no notes to court, only practiced by translating Greek poetry, and had firm views about the sound of Latin. ${ }^{25}$ (He seems also, judging by the fragment Quintilian preserves, to have been a reader of Lucretius. ${ }^{26}$ Syme's hypothesis is additionally convincing, because it helps explain, as we shall see, an otherwise vague reference in a satire of Horace; it is much likelier, too, as Syme argues, to have the coevals Servius and Messalla arguing a case in the triumviral period than the elderly jurist and Messalla at the end of 44 B.C.E. If all this is true, we can add two more speeches to the triumviral period.

4. In 38 B.C.E. a speech was given in Rome by Antony's general P. Ventidius Bassus, who routed Labienus and the Parthians from Asia and then Syria in three great battles and then returned to Rome to celebrate a triumph.$^{27}$ Fronto, the only source for this oration, says that it was

${ }^{22}$ Inst. 6.1.20 (supplying Messalla) and 10.1.22; note also Fest. p. 140.11 and 194.18 Lindsay. It is the first passage from Festus that strongly suggests this is an inheritance case.

${ }^{23}$ On Servius' speech, see (in addition to the sources in the previous note) Quint. Inst. 4.2.106-7 (source of the quotation).

${ }^{24}$ The passages are listed by Syme 1981, 421-22; cf. Malcovati $O R F^{4}$ no. 118.

${ }^{25}$ For all the evidence, see Syme 1981, esp. 425-26.

${ }^{26}$ With "somnone te languidum an gravi lethargo putem pressum" (containing the choice lethargo), cf. "gravi lethargo fertur in altum / aeternumque soporem oculis nutuque cadenti ..." " "it is carried by a heavy lethargy into deep and never-ending sleep with eyes and nodding head drooping ...," Lucr. 3.465-66).

27 "The famous Ventidius, after he defeated and dispersed the Parthians, to extol his own victory borrowed a speech from Sallust" ("Ventidius ille, postquam Parthos fudit fugavitque, ad victoriam suam praedicandam orationem a C. Sallustio mutuatus est," Front. ad Ver. 2.1.9); for the triumph, the Tr. Cap. for 38 B.C.E. read "Publius Ventidius, the son of Publius, proconsul, over Mount Taurus and the Parthians on 27 November" (P. Ventidius P.f. procos. ex Tauro monte et Partheis V. $k$. Decem). 
delivered "to extol his victory." In earlier days, it had been the custom for a triumphing general to give an account of his res gestae a few days after the triumph itself in a contio before the people. ${ }^{28}$ This must have been the occasion for Ventidius Bassus' oration, which, according to Fronto, owed a debt to Sallust, not, apparently, because the historian served as ghost-writer but because its contents showed his influence. ${ }^{29}$ (Fronto's admiration of Sallust will explain, in turn, his interest in Ventidius' speech.)

5. Just a year before, a partially preserved inscription tell us, in the aftermath of Labienus' takeover of Asia and his subsequent expulsion by Ventidius Bassus, the Senate deliberated on what assistance to give the Carian city of Aphrodisias, which, unlike other neighboring communities, had stayed loyal to the triumvirs. ${ }^{30}$ The two consuls, Calvisius Sabinus and Marcius Censorinus, spoke, as did Antony and Octavian themselves, in favor of reaffirming Rome's previous ties to Aphrodisias. The Senate concurred and also supported a subsequent motion of Marcius Censorinus and Calvisius Sabinus that bequeathed extra privileges on the Aphrodisians and their ambassador, who, as another inscription shows, had his own private meeting with Octavian, perhaps before the Senate passed its decree. ${ }^{31}$

6. Also in 37 B.C.E., Marcius Censorinus spoke to the Senate about privileges for another Carian city, Stratonicea, that had fought against Labienus. Since the inscription recording the senatus consultum is badly preserved, we can infer virtually nothing about the contents of his speech. ${ }^{32}$

7. Finally, a recently published inscription can make us almost certain of one more triumviral oration, given by Antony's friend Fonteius Capito, whom we meet in Maecenas' company on the diplomatic mission Horace describes in Satires $1.5 .{ }^{33} \mathrm{He}$ apparently spoke before the people

${ }^{28}$ See Livy 45.40 .9 , in reference to the triumph of L. Aemilius Paullus. Cf. also Val. Max. 5.10.2.

${ }^{29}$ For a full and recent discussion, see Leisner-Jensen 1997.

${ }^{30}$ For this and what follows, see the text and commentary of Reynolds 1982, no. 8.

${ }^{31}$ See the text and commentary of Reynolds 1982, no. 12.

${ }^{32}$ See the text and commentary of Sherk 1969, no. 27.

${ }^{33}$ For the inscription and commentary, see Crawford 1996, no. 36, and also now the full discussion of Cos in the triumviral period in Buraselis 2000. For Fonteius Capito: "meanwhile Maecenas appeared and Cocceius together with Fonteius Capito, a gem of a fellow: not a better friend could Antony have" ("interea Maecenas advenit atque / Cocceius Capitoque simul Fonteius, ad unguem / factus homo, Antoni, non ut magis alter, amicus," Hor. Sat. 1.5.31-33). 
(in what capacity remains uncertain) on behalf of a law bestowing various privileges on the island community of $\operatorname{Cos}^{34}$ The wording of the law subsequently passed, which is what the stone, found on Cos, partially preserves, may give a hint of the speech's contents. The Coans were to be rewarded because the triumvir Marcus Antonius had recognized their fides, even bringing it to the attention of the Senate, which in turn must have been seeking ratification of a decree by the plebs or populus. ${ }^{35}$

\section{III}

Altogether, the evidence described above may yield as many as thirteen different speeches: three by the triumvirs themselves, the others by Asinius Pollio, Sempronius Atratinus, Messalla Corvinus, Calvisius Sabinus, Marcius Censorinus, Ventidius Bassus, and (it would seem) the younger Sulpicius Rufus and Fonteius Capito. Most of this latter group consisted of young men, though some of these had gotten their start in the age of Cicero: Sempronius Atratinus, as we saw, but also Asinius Pollio, who spoke against Gaius Cato in 54 B.C.E., and Messalla Corvinus, mentioned in several letters of Cicero. ${ }^{36}$ It is important to remember this when we try to imagine what (oratorical) life was like for these men under the triumvirate. The material gathered here suggests that it was more difficult to be outspoken on great affairs of state than it had been at the height of Cicero's career. Pollio checked his tongue at the trial of Aelius Lamia, while speakers before the Senate and People such as Messalla Corvinus, Sempronius Atratinus, and (most likely) Fonteius Capito spoke only in conformity with the views of the triumvirs (doubtless made known to them by prior arrangement). Of course, though, as observed above, in earlier times, too, a man would have to watch what he said for various reasons.

Yet individuals did continue to speak publicly, a point I shall return to in a moment. I want first to dwell more fully on the reasons for the lack of a fuller political dialogue in Rome. Most importantly, the autocracy of the triumvirs, who ushered in their rule with a revival of

\footnotetext{
${ }^{34}$ The fragmentary inscription records only that Fonteius was 'priest.' Some scholars have assumed that when the law was passed (perhaps in 39 B.C.E.), he was tribune (and so the law would have been passed in the concilium plebis): see, e.g., Broughton MRR 3.93.

${ }^{35}$ It was not customary for the Senate to seek ratification for a decree concerning foreign relations; the passage of a law by the plebs or populus may have been thought an extra protection in this uncertain period.

${ }^{36}$ Pollio's speech against Cato: Sen. Contr. 7.4.7; Quint. Inst. 12.6.1; Messalla in Cicero's letters: Att. 12.32.3, 15.17.2; ad M. Brut. 1.12.1,1.15.1-2.
} 
Sulla's proscriptions, must have intimidated individuals and prevented them from speaking. While evidence for this is hard to find (not surprisingly, given Octavian's final victory), it is instructive to consider Cicero's worry in the spring of 44 B.C.E. about whether to attend and speak at a Senate meeting on 1 June of that year, where there was to be discussion of a redistribution of provincial commands greatly to Antony's favor. As soon as he heard, from Atticus, a report of the meeting's agenda, Cicero wondered whether a free discussion would be allowed. Several days later he wrote from Puteoli, "I am warned by many in these parts that I shouldn't be in the Senate on the first of the month; for soldiers are said to have been collected secretly for this day" ("equidem in his locis moneor a multis ne in senatu Kalendis. dicuntur enim occulte milites ad eam diem comparati ...," Att. 14.22 = SB 376.2). Other warnings poured in, from Hirtius, who said that he was planning to stay away from the meeting, and Varro, who sent Cicero a letter-its author's name slashed out-reporting that there was "most insolent talking" among the veterans (improbissime loqui, $15.5=\mathrm{SB} 383.3$ ). It is no wonder that Cicero and Hirtius stayed away. Similar worries, and perhaps similar reports of soldiers lurking around, must have kept senators away from meetings in the triumviral period too.

Rumors about soldiers in the Senate may have been bad enough, but the incontestable fact of Cicero's murder early in the proscriptions was even more sobering. The display of the great orator's head on the Speaker's platform seared the imagination of contemporaries, as we will see. ${ }^{37}$ But it is only the late writer Macrobius who makes the obvious point when he records Fescennines attributed to Asinius Pollio: "But I keep my mouth shut. It's not easy to write against one who can write back your death warrant" (non est enim facile in eum scribere, qui potest proscribere, quoted at Sat. 2.4.21). The witticism, which need hardly be taken as authentic, does offer another explanation of why we hear of so little political oratory of substance from the triumviral years.

Leaving aside the question of intimidation, we should not overlook the real heartache or disgust this lack of debate may have produced for someone like Pollio. Again, a letter of Cicero, this time written during the dictatorship of Caesar, is suggestive. In it, the orator writes bitterly to $\mathrm{Cn}$. Plancius, who had praised the orator for maintaining his dignitas:

${ }^{37}$ See especially the material gathered at Sen. Suas. 6-7, and the discussions of Kaster 1998 and Richlin 1999. 
Ego autem, si dignitas est bene de republica sentire et bonis viris probare quod sentias, obtineo dignitatem meam; sin autem in eo dignitas est si quod sentias aut re efficere possis aut denique libera oratione defendere, ne vestigium quidem ullum est reliquum dignitatis ...

(Fam. $4.14=$ SB 240.1)

I for my part am maintaining my standing, if "standing" means holding sound views about the state and having what you think be approved by good men; but if "standing" means either that you can put into effect what you think or that you can defend it in free speech, then not even a trace of standing is left in us.

The contrast between sentire and probare, on the one hand, and the more vigorous efficere and defendere, on the other, underscores the impotence of a man living under autocratic rule, just as the emphatic repetition of the word dignitas suggests how autocratic rule can change the meaning of some of the most fundamental ethical concepts. One also senses, though, how Cicero, feeling his own expression constrained, appeals to an ideal of freedom of speech that had never been the reality at Rome.

But in any case, if a perception that libertas was diminished made it seem hard to achieve dignitas through oratory, it was natural that men of senatorial standing, like Pollio, would instead turn to other pursuits to fill their time, just as Cicero wrote a flood of treatises after his return to Rome in 46. "I shall only say," he wrote Sulpicius Rufus (the father), "that ever since I saw that there was no place in the Senate or the Forum for that skill to which I had devoted myself, I directed all my attention and efforts to philosophy" ("tantum dicam ... postea quam illi arti cui studueram nihil esse loci neque in curia neque in foro viderim, omnem meam curam atque operam ad philosophiam contulisse," Fam. $4.3=$ SB 202.4). One good illustration, from the triumviral period (at least in part), is given by the career of Q. Aelius Tubero, who unsuccessfully prosecuted Ligarius before Caesar in 46 B.C.E. ${ }^{38}$ Apparently disgusted by the experience, Tubero forever abandoned oratory and turned to the study of both public and private law and then, in the triumviral period, began a history of early Rome written in the Thucydidean style he favored. ${ }^{39}$ Pollio, too, commenced the writing of his history in the triumviral period. The writing of philosophy, jurisprudence, history: that was now a more

${ }^{38}$ See Malcovati $O R F^{4}$ no. 175 for the testimonia.

${ }^{39}$ On Tubero see the discussions of Wiseman 1979, 135-39 and Bauman 1985, 113-17. 
attractive pastime than it had been before. In those activities you could still make recommendations on what was good for the res publica; in history you could compose a fiery speech. It is no coincidence that the vigorous defense of history writing as a full-time occupation-rather than a senator's leisure activity -in Sallust's monographs, especially the Bellum Catilinae, was penned in the years after Caesar's death. ${ }^{40}$

Fear of speaking, the reduced rewards of eloquence, and the greater satisfaction that the writing of history or jurisprudence could bring might be sufficient to explain the changed role of oratory in triumviral Rome. But we can finally suggest two other reasons, less significant but certainly not irrelevant. The first is that civil war simply took people away from Rome, often for years at a time. Messalla, for instance, arrived in Brutus' camp in July 43, along with a letter from Cicero that praised his eloquence. But that eloquence would have no chance to shine in Rome until very late in the year $40 .{ }^{41}$ (And then, one may speculate, the compliant speech he gave on behalf of Herod was, at least in part, to show gratitude to the man who had spared him.) Messalla would spend much of the 30s away from Rome too. ${ }^{42}$ At the same time, civil war also kept listeners away from Rome. Seneca the Elder complains that he would have heard Cicero speak but was deprived because "the violent madness of the civil wars, which then was raging freely over the whole world, confined me to my colony" ("bellorum civilium furor, qui tunc orbem totum pervagabatur, intra coloniam meam me continuit," Contr. 1. praef. 11). In a letter to Cicero written in 43 (Fam. 10.31 = SB 368.5-6), Asinius Pollio complained that because of civil war he was kept away from the literary society he enjoyed at Rome.

A second reason is that civil war, despite-or rather, because of-all its illegality, held fewer opportunities for criminal prosecution. Men could get away with deeds they would be held accountable for in times of peace, as Cicero pointed out to Caesar after the earlier civil war with Pompey:

${ }^{40}$ On the dating of the Bellum Catilinae to the end of 42 or 41, see Syme 1964,127-29. An anonymous reader points out that a contrast can be drawn here with Cicero's criticisms of the elder Sulpicius at Mur. 23-29; that man's study of jurisprudence is faulted precisely for removing him from public life.

${ }^{41}$ For Messalla's movements in the months and years after Philippi see esp. Jos. $A J$ 14.325, 384; BJ 1.243, 284.

${ }^{42} \mathrm{He}$ fought with Octavian in the war against Sextus Pompey, and also campaigned in Illyricum and perhaps the Alpine regions in the later 30s; he also fought, for Octavian, at Actium. On his career see Hammer 1925 and Syme 1986, 201-16. 
Omnia sunt excitanda tibi, C. Caesar, uni, quae iacere sentis, belli ipsius impetu, quod necesse fuit, perculsa atque prostrata; constituenda iudicia, revocanda fides, comprimendae libidines, propaganda suboles, omnia, quae dilapsa iam diffluxerunt, severis legibus vincienda sunt.

(Marc. 23-24)

By you alone, Gaius Caesar, must everything be revived which you see lying in ruin, overthrown and shattered by the violence of the war itself, as was inevitable; courts must be established, credit must be restored, vices must be put down, the birthrate must be increased, everything which has decayed and gone to ruin must be bound up by strict laws.

He continues by saying that "the safeguards of the state's stability," which would include its courts, were bound to be lost. ${ }^{43}$ Asinius Pollio actually made the same point in his Histories, rather backhandedly, when he accounts for the success Cicero did enjoy during his life. Referring to the years between Sulla's death and the outbreak of war in 49, he says, "a long period of peace, in whose arts he had been trained, was granted to him; and with the courts made to conform with their old strictness, a very large crowd of guilty men came forward, many of whom he saved and so bound to himself in patronage" ("tum pax diutina, cuius instructus erat artibus, contigit; namque ad priscam severitatem iudiciis exactis maxima noxiorum multitudo provenit, quos obstrictos patrocinio incolumes plerosque habebat," quoted at Sen. Suas. 6.24).

If the rule of the triumvirs, the bloody wars they fought, and the leeway given to their associates make it clear why there was less outspoken oratory, it is also clear-to return to a point made above-that oratory did not end altogether. Though they lived in a time of rapid change, orators such as Sempronius Atratinus and Valerius Messalla did not lose all sight of the ways in which a reputation for eloquence had been won in prior years. Under the rule of Antony, Octavian, and Lepidus, the material presented in section III above suggests that they-and others - could and did go on giving speeches that discussed public affairs, before the Senate and at contiones. Evidence for forensic activity, it is true, is more limited, at least in the quaestiones perpetuae. It is entirely possible, though, that the centumviral court, where Pollio would later find a way to make a name for himself, was already beginning to gain the greater prominence it enjoyed in imperial times. ${ }^{44}$ If the trial involv-

${ }^{43}$ Cf. also Sen. Contr. 7.2.8.

${ }^{44}$ Pollio's speeches on behalf of Urbinia's heirs were familiar in later times: see Tac. Dial. 38.2 (assigning them to "the middle period of the rule of the deified Augustus" [mediis divi Augusti temporibus]), along with Quint. Inst. 4.1.11, 7.2.4-5, 7.2.26. Full details are to be found at Malcovati $O R F^{4}$ no. 174. 
ing Aufidia was, as seems quite likely, an inheritance case, it might have been heard in this civil court. In this venue, we should note, there may have been more opportunity for a certain type of outspokenness, not on great affairs of state, but in criticizing the opposing counsel, for instance, as Pollio once did (Quint. Inst. 4.1.11).

But even when speeches were less outspoken, we cannot assume they were always less creative. To glance again a few years back, Cicero's speech thanking Caesar for the restoration of Marcellus presented a new type of challenge for the orator and one he enjoyed some success in meeting. D. S. Levene (1997, 68-77), for instance, demonstrates the subtlety with which Cicero attributes both human and divine attributes to Caesar as part of an argument, not simply as empty praise. Similar challenges must have been faced under the triumvirs, even if Cicero was not around to meet them. Indeed, Quintilian specifically mentions that the rhetorical mode of deprecatio, the plea for mercy, had some importance both in the Caesarian and triumviral periods before becoming essential with the emperor's court. ${ }^{45}$ Distasteful as this development might seem to the lover of liberty, I emphasize again that we cannot imagine that deprecatio required no skill or that it had no impact on its listeners. A well-delivered speech in such a context could, for instance, make contributions to the ideology of clementia. There were other ways, too, in a speech before the Senate or the people, to display talent, a point to which I shall return in the final section.

\section{IV}

It is important here to dwell a bit longer on the question of outspokenness (what the Romans called libertas), an attribute of oratory lacking under the triumvirs during public debates over affairs of state. It might be objected that our sources, especially since they are colored by Octavian's

${ }^{45}$ Discussing defense speeches in the courts, Quintilian writes: "A plea for mercy which is without any pretense of being a defense is unusual, and only used before judges who are not held to a set form of verdict. Even those speeches given before Caesar and the triumvirs on behalf of men of the opposite party, although they do contain pleas, also bring in justifying arguments ..." ("deprecatio quidem, quae est sine ulla specie defensionis, rara admodum et apud eos solos iudices qui nulla certa pronuntiandi forma tenentur. Quamquam illae quoque apud C. Caesarem et triumviros pro diversarum partium hominibus actiones, etiam si precibus utuntur, adhibent tamen patrocinia ...”) (Inst. 5.13.5). He continues that deprecatio is in order "before the emperor or some other person, who is allowed to judge whatever way he wishes" (apud principem aliumve, cui utrum velit liceat, Inst. 5.13.6). Cf. Cic. Inv. 2.104 and Herenn. 1.24. 
version of events in his autobiography, simply do not record traces of opposition to the triumvirs. We can turn back now to the Greek authors discussed above and show that they do reveal (in addition to Lucius Antonius' speech) criticisms that were issued by eloquent individuals, on several different occasions, against one or several of the triumvirs. The circumstances of each of these will show just how difficult, even impossible, any kind of debate really was, though they will also suggest one way in which a more unreserved type of speaking was possible.

The most famous denunciation of the triumvirs, it was said, came from the lips of Hortensia, daughter of the great Republican orator who died in 49 B.C.E. and whose son fell at Philippi in 42 B.C.E. ${ }^{46}$ The occasion was the triumvirs's unusual decision to tax the richest women of Rome when the proscriptions failed to bring as much revenue as they had hoped. Appian (B.Civ. 4.32-34) gives by far the fullest version of the incident. Hortensia, he says, marched with a delegation of women through the Forum to the tribunal of the triumvirs. The crowd stood to the side to let them pass, listened sympathetically as she sternly criticized the triumvirs, and then protested when the triumvirs ordered the women dragged off with lictors. The next day, the three men announced a reduction in the number of women to be assessed. If all this is true, Hortensia's protest was partially successful in changing one detail of the triumvirs' policies, though the attention Appian devotes to the episode suggests that it was not part of any sustained dialogue on the rule of the triumvirs more generally.

It is difficult to know how much of this truly remarkable narrative to believe. Valerius Maximus includes Hortensia as one of three examples in a chapter on women whose "natural condition and the cloak of modesty could not keep silent in the Forum and the courts of law" ("condicio naturae et verecundiae stola ut in foro et iudiciis tacerent cohibere non valuit," 8.3 pr.; the other two women cited both spoke before the praetor). Quintilian comments that in his day people read "the speech that Hortensia, daughter of Quintus, delivered before the triumvirs" ("Hortensiae Q. filiae oratio apud triumviros habita," Inst. 1.1.6). If we assume that these authors are not simply inventing, it would seem that Hortensia did make before the triumvirs some kind of criticism about their plan to tax the women, memory of which survived into later times. It may even have been, as Valerius suggests, in the Forum and so would have taken

${ }^{46}$ She appears as Malcovati $O R F^{4}$ no. 90 . 
place at the triumvirs' tribunal where, apparently, other petitions were heard during the time of the proscriptions. ${ }^{47}$

Some additional evidence does survive concerning the nature of these requests. It is to be found in the so-called Laudatio Turiae, the massive, though only partially preserved, inscription from Rome that records the praises a husband gave his wife, probably in the last decade B.C.E. ${ }^{48}$ Bravely hiding him during the proscriptions (he says), she successfully petitioned Octavian for his restoration and then went before Lepidus, the triumvir in charge of Rome, in Octavian's absence to get his colleague's decision recognized. This was, according to the husband, a less successful encounter:

[... ad eius] pedes prostrata humi [n]on modo non adlevata, sed tra[cta et servilem in] modum rapsata, livori[bus c]orporis repleta, firmissimo [animo eum admone]res edicti Caesaris cum g[r]atulatione restitutionis me[ae auditisque verbis eti]am contumeliosis et cr[ud]elibus exceptis volneribus pa[lam ea praeferres,] ut auctor meorum peric[ul]orum notesceret.

... you, prostrate on the ground before his feet, were not only not lifted up, but were dragged and carried off like a slave. Your body was covered with bruises, but most firmly you kept reminding him about Caesar's (i.e., Octavian's) edict and satisfaction at my restoration and, although you had to listen to Lepidus' insulting words and endure cruel wounds, you kept on putting forward your case in the open so that the person responsible for my trials would be publicly disgraced.

Only later, apparently, was the edict recognized. Alain Gowing (1992b) has convincingly argued that the husband's emphasis on Lepidus' violence is exaggerated, a reflection of Octavian's final victory and his colleague's disappearance from the scene after 36 B.C.E. All the same, the account is unlikely to be a complete fabrication and does suggest that an untrammeled criticism of the triumvirs was not the way one tried to win any favor that was being sought from them. The historical Hortensia's petition, then, was perhaps not as bold as Appian says, perhaps not quite the oratio Quintilian knew. That oratio could have originated at a later time, perhaps as a rhetorical exercise; if so, it would, like the speech Appian composes below).

${ }^{47}$ On the tribunal see App. B.Civ. 4.37 and the so-called Laudatio Turiae (discussed

${ }^{48}$ I print the text of Wistrand 1976. The dating depends on the reconstruction of the couple's life as given by Durry 1950, lxiii-lxiv. 
in his history for Hortensia, speak to a desire to create a more outspoken detractor of the triumvirs than the historical record offered..$^{49}$

Another obvious, but not insignificant, similarity between Hortensia and the wife of the laudatio is that both were women. They did not rely, as they would have in normal circumstances, on a male advocate. And, in fact, Valerius Maximus specifically says that no man would dare offer the wealthy matrons legal aid $(<n e c>$ quisquam virorum patrocinium iis accommodare auderet, 8.3.3). While the Tiberian author is trying to exonerate Hortensia of her unwomanly behavior, his statement is likely to be true and should be related to another anecdote in his handbook about a contemporary of Hortensia:

Age, Cascellius, vir iuris civilis scientia clarus, quam periculose contumax! nullius enim aut gratia aut auctoritate compelli potuit ut de aliqua earum rerum quas triumviri $<$ dono $>$ dederunt formulam componeret, hoc animi iudicio universa victoriae eorum beneficia extra omnem ordinem legum ponens.

Behold, Cascellius, pre-eminent in his knowledge of civil law, how perilously defiant! For he could not be forced, either by the influence or authority of anyone, to draw up a formula concerning any of those things which the triumvirs had conferred; for in his opinion he placed all the benefactions of their victory beyond the whole range of the laws.

Aulus Cascellius, a lively and independent jurist, several of whose opinions are preserved in the Digest, was also remembered by posterity for his sharp wit. ${ }^{50}$ Even in the triumviral period, he allegedly remained true to character. Perhaps serving as praetor, otherwise for his legal knowledge, he was asked to draft a formula to legalize the (irregular) transfer of property by the triumvirs and refused. ${ }^{51}$ Valerius Maximus goes on to say that when his friends warned him "because he spoke at length and too freely about the times they lived in ... he replied that two things, which seemed most distressing to men, gave him a significant license: old age and childlessness" ("idem cum multa de temporibus liberius loqueretur ... duas res, quae hominibus amarissimae viderentur, magnam sibi licentiam praebere respondit, senectutem et orbitatem"). While Cascellius may have

${ }^{49}$ The period of the proscriptions was popular with the declaimers known from the pages of Seneca the Elder; see esp. Contr. 4.8, 6.4, 7.2, 10.3; Suas. 6-7.

${ }^{50} \mathrm{~A}$ collection of jokes is noted at Dig. 1.2.2.45. Quint. Inst. 6.3.87 and Macr. Sat. 2.6.1-2 preserve examples of his wit.

${ }^{51}$ On the presumed praetorship, see the full (but necessarily inconclusive) discussion of Bauman 1985, 117-23. 
criticized the triumvirs, there is no sign that he did so publicly. The usual misfortunes of childlessness and old age lessened his fears, but, Valerius' story suggests, those around him were much more hesitant to speak.

Another protest against triumviral policy was delivered by Hybreas, a rhetorician from the Carian city of Mylasa who is quoted several times in the pages of Seneca the Elder. ${ }^{52}$ When Antony levied a heavy tax on provincials of Asia, Hybreas, well-known for his outspokenness on other occasions, delivered a brave criticism, a copy of which may have survived into later periods. ${ }^{53}$ But as with the petition of the wife in the laudatio, the circumstances of this speech (which, of course, was not delivered at Rome but in Ephesus) again suggest why true outspokenness in this situation was impossible. For his speech to succeed, it had to stay respectful of the triumvir addressed. It attacked Antony's policy, to be sure, but not Antony himself. In fact, Plutarch says, the speech had parts composed in a manner that appealed to Antony's own style.

Finally, we turn to one speech, given in Rome, that does seem to have genuinely attacked one of the triumvirs. At the start of 32, the consul Sosius, a loyal partisan of Antony, delivered before the Senate a vigorous oration against Octavian and proposed to outlaw him before he was vetoed by the tribune Nonius Balbus. ${ }^{54}$ The opening months of 32 were a strange time, since, it is almost certain, the triumvirate had officially expired on the last day of 33, and, for a brief period, something approaching the full political sparring of the Republic returned to Rome. ${ }^{55} \mathrm{But}$ what happened after Sosius' attack once more made clear the futility of speeches of protest in Rome.

Octavian himself was not at the session, indeed, was not even in Rome, though he paid close attention to developments there. He returned only later and then convened his own meeting of the Senate where, attended by armed soldiers and seated on a third ivory chair between the two consuls, he spoke in defense of himself and denounced Sosius and Antony. Hearing nothing in response, he announced a future meeting of

${ }^{52}$ See Contr. 1.2.23, 1.4.11, 2.5.20, 7.4.10, 9.1.12, 9.1.15, 9.6.16; Suas. 4.5, 7.14.

${ }^{53}$ Plut. Ant. $24.7-8$, the only source for this incident, places it in 41 B.C.E.; Buchheim $1960,12-13$ argues persuasively that it should belong to the triumvir's second visit to the city, in 33 B.C.E.. On Hybreas' outspokenness, see the valuable testimony of Strabo 14.2.24.

${ }^{54}$ The only source for the Senate meeting and its aftermath is Dio 50.2.3-7.

${ }^{55}$ The triumvirate first expired at the end of 38 B.C.E., and most scholars agree its renewal (in later 37) was dated retroactively to 1 January 37. For a full argument of this view with detailed analysis of the sources, see Fadinger 1969, 84-136. Gabba 1970, lxviii-lxxix, by contrast, argues, mainly on the basis of App. Ill. 28, that the triumvirate was to expire at the end of 32 B.C.E.. 
the Senate at which he would offer written proof of Antony's wrongdoing. Thus silenced, Sosius and his colleague soon fled to Antony at Ephesus along with as many as three hundred senators. ${ }^{56}$ It was with swords, more than pens, that the final contest would be decided.

Still, speeches were not irrelevant in the final struggle-or before. It is not difficult to imagine that more than one oration was heard in the Senate in 32 B.C.E. denouncing Antony in a style reminiscent of late Republic oratory and Cicero's Philippics in particular. The scurrilous and rather creative charges brought against Antony by Calvisius Sabinus, enumerated at Plut. Ant. 58.5-6, may have first aired in speeches in the Senate or Forum. Likewise, Messalla's claim that Antony had taken to using gold chamber pots may stem from a speech later published. ${ }^{57} \mathrm{~A}$ few years before, invective against Sextus Pompey would not have been out of order. In certain circumstances, the abusiveness of earlier oratory was permitted, though it should not be confused for a total freedom of speech. It had to suit whoever was in charge of Rome.

\section{V}

After this examination of the occasional criticisms that were made against the triumvirs, it remains now to return to the corpus of speeches assembled in section III above to draw some conclusions concerning the typical role of oratory in triumviral Rome. From the list of orators assembled, two above all enjoyed a reputation for eloquence in later generations, Asinius Pollio and Messalla. Especially famous is Quintilian's verdict in the Institutio Oratoria:

Multa in Asinio Pollione inventio, summa diligentia, adeo ut quibusdam etiam nimia videatur, et consilii et animi satis; a nitore et iucunditate Ciceronis ita longe abest, ut videri possit saeculo prior. At Messalla nitidus et candidus et quodam modo praeferens in dicendo nobilitatem suam, viribus minor.

(Inst. 10.1.113)

There was much effort at devising arguments in Pollio, great precisionindeed, too much, for some anyway-and sufficient sense and spirit; but he is so far removed from Cicero in polish and style that he could seem to have lived a century before. Messalla, on the other hand, is polished and

${ }^{56}$ Octavian had 700 senators with him in Italy, according to $R G 25.3$, while Dio 52.42.1 gives the Senate's full size as 1000 .

${ }^{57}$ Plin. $N H$ 33.50. Malcovati $O R F^{4}$ no. 176 assigns the charge to a speech Contra Antonii litteras, but as she notes, this work may only have been a pamphlet. 
lucid, and somehow shows his noble rank in his speech; but in strength of speaking he is inferior.

Talents they had, Quintilian says, but neither enjoyed that genuine gift for persuasiveness that blessed Cicero, who is praised at length in a passage immediately preceding this description of his successors (Inst. 10.1.105-12).

But reading between the lines, and thinking more properly about the historical circumstances in which they worked, one can see that what these two men, and the others speaking in the triumviral period, could strive for most was a unique style: in that, rather than outspokenness, would have to lie their eloquence. This does not mean that their work lacked originality, or that contemporaries failed to appreciate their efforts; indeed, the future emperor Tiberius is said to have taken Messalla as his model (Suet. Tib. 70). Pollio labored for a brevity and bluntness reminiscent of an earlier period, while Messalla experimented with the sounds of Latin words until he found the most euphonious arrangements possible. Doctrina and diligentia, rather than libertas, would be the hallmarks of the new age.

This emerges clearly too from Horace's Satires, which give precious evidence, from the triumviral period itself, of the diminished role of outspokenness under the three men but also of the achievements that were recognized in contemporary oratory. ${ }^{58}$ In the poem that ends his first book, probably completed around 35 B.C.E., Horace, defending his decision to write satire and the style he adopted-so different from that of Lucilius, inventor of the genre-imagines a critic celebrating the ability of other poets to blend Greek words into Latin verses, like Chian wine into Falernian. The satirist responds by asking whether one should do the same in court too:

scilicet oblitus patriaeque patrisque, Latine cum Pedius causas exsudet Publicola atque Corvinus, patriis intermiscere petita verba foris malis ...?

Doubtless you, forgetting father and fatherland alike, prefer to intermingle native words with those sought from abroad, while Pedius Publicola and Corvinus are working out their cases in Latin with great effort ...?

${ }^{58}$ Interesting discussions of Horace's redefinition of satire's libertas, and its political implications, include DuQuesnay 1984, 27-32 (seminal), Freudenburg 1993, 86-108, Freudenburg 2001, 44-51, and Gowers 2005. 
A skilled defense of his own practices, Horace's lines also compliment his friend Messalla by hinting at that man's great efforts at speaking as pure a Latin as possible. ${ }^{59}$ (Also, let us observe, another triumviral orator emerges: Pedius Publicola, quaestor in the year 41, as an inscription shows, and son of the man elected to serve as consul with Octavian in 43. ${ }^{60}$ ) That these lines compliment Messalla and Pedius Publicola, who was Messalla's nephew, is confirmed by the appearance of Messalla later in the poem, along with several other names, in a list of "learned men" (doctos) whom Horace envisions as his ideal readers (lines 84-88). Also included are Pollio and Servius (who should be the younger Sulpicius Rufus) and three others, Messalla's brother, Furnius, and Bibulus. Since Furnius (like his son) is known from other sources for his eloquent oratory ${ }^{61}$ it may be that Bibulus (i.e., L. Calpurnius Bibulus, who fought at Philippi but then surrendered to Antony) and Messalla's half-brother (i.e., Gellius Poplicola, consul of 36 B.C.E.) also enjoyed success in public speaking. What seems to emerge, in any case, is a list of men singled out for their discriminating sense of style, rather than their outspokenness. They form a natural complement to Horace's own Satires, which themselves also avoid a Republican outspokenness, the direct attack-by name-in which Lucilius indulged.

A quest for style, for elegance, even for purity of Latin, was one consequence the triumvirate had on oratory; a second, we can mention in closing, was the beginnings of a cult of Cicero's memory and with it an idealized view of Republican libertas that made it seem less constrained than it was. In the years following Cicero's death, he came to be revered

${ }^{59}$ Quintilian (Inst. 1.7.23, 35; cf. 9.4.38) reveals that Messalla wrote books on words and letters (including $s$ ), approved of using duapondo and trepondo (1.5.15), as well as gladiola (1.6.42), but insisted on rendering the Greek name Euthias as Euthia (1.5.61)-this last a neat illustration of Horace's claims. He enjoyed translating Greek oratory into Latin and even set himself the challenge of Hyperides' defense of Phryne (10.5.2). Porphyrio, in a confused note on Hor. Sat. 1.10.28, says that Messalla was the first to say funambulus (instead of the Greek equivalent). Seneca the Elder calls him "a man who showed a most careful regard above all for the Latin language" (Latini utique sermonis observator diligentissimus, Contr. 2.4.8); in comparison to Cicero he is "more painstaking in his choice of words" (in verbis magis elaboratus, Tac. Dial. 18.2); Tiberius' refusal to use any Greek in the Senate is one instance of Messalla's influence on him (Suet. Tib. 70-71).

${ }^{60} I L S$ 3201. For the consul, see Broughton MRR 2.336-37.

${ }^{61}$ Both father (pr. 42 B.C.E.) and son (cos. 17) were orators (see Jerome's chronicle for the year 37 B.C.E.): Horace's lines are likelier to refer to the father, who had the greater reputation for eloquence in the 30s B.C.E.: see Cic. Fam. 10.26.2 and Plut. Ant. 58.11. Syme 1981, 425 first opted for the son, then the father: Syme 1986, 394. See also Malcovati $O R F^{4}$ no. 151 (for the father). 
as Rome's last truly great orator and cast, sometimes with the aid of fiction, into a martyr for Republican outspokenness. ${ }^{62}$ It was perhaps natural that the freedman Tullius Laurea would honor the memory of his former master after his death. Staying on to work at Cicero's estate at Puteoli, which fell to the Antonian Antistius Vetus, Laurea wrote an epigram shortly after Cicero's death when, not coincidentally, it seemed, a spring of hot water burst forth that proved to be beneficial for eye complaints: ${ }^{63}$

Quo tua, Romanae vindex clarissime linguae, silva loco melius surgere iussa viret atque Academiae celebratam nomine villam nunc reparat cultu sub potiore Vetus, hoc etiam apparent lymphae non ante repertae, languida quae infuso lumina rore levant. nimirum locus ipse sui Ciceronis honori hoc dedit, hac fontes cum patefecit ope, ut, quoniam totum legitur sine fine per orbem, sint plures oculis quae medeantur aquae.

(qtd. at Plin. NH 31.8)

In the place where, most famous champion of the Latin tongue, the grove you bade to rise grows greener, and Vetus now renews with more careful cultivation the villa honored with the name of Academe, here also are seen waters not found before, which, when a drop of them is instilled, restore exhausted eyes. Without a doubt, the place itself gave this to honor its master Cicero, when it revealed springs with this power so that, because he is read throughout the world to its ends, there may be more waters to heal the eyes.

Its pietas not withstanding, the poem still casts light on the world after Cicero's death. Now, in the world of the triumvirs, in the world of Antistius Vetus (who is tactfully complimented in the poem's opening couplets), the "champion of the Latin tongue" is gone, but his works, at least, will go on to be appreciated. If the curia and forum had less to offer than when Cicero was alive, at the edges of the earth there still could be assiduous readers of Cicero's published works. In that, at least, the rhetoricians we know from the pages of Seneca the Elder could take some consolation. ${ }^{64}$

${ }^{62}$ See especially Kaster 1998 and Richlin 1999; and on the development of the tradition, Roller 1997.

${ }^{63}$ Courtney 1993, 182-83 gives a brief commentary.

${ }^{64}$ See especially the material gathered in Suas. 6-7. 
And it is Seneca, in fact, who preserves part of another poem that honored Cicero's memory, written by the poet Cornelius Severus, that included the lines, "One day destroyed a glorious age ${ }^{65}$ and the eloquence of the Latin tongue, struck by grief, grew silent in sadness" ("abstulit una dies aevi decus, ictaque luctu / conticuit Latiae tristis facundia linguae," at Suas. 6.26). ${ }^{66}$ This, Seneca argues, perfected a slightly cruder line, crafted by the Corduban Sextilius Ena. Giving a recitation at the house of Messalla, to which Pollio had been invited, this poet had begun his performance with a verse that was greeted with some applause: "Cicero must be mourned, and the silence of the Latin tongue" (deflendus Cicero est Latiaeque silentia linguae, quoted at Suas. 6.27). Disgusted, for the metaphor deftly condemned all of his efforts at eloquence, Pollio left the recitation in a huff and criticized Messalla for allowing it to continue. "I do not intend to listen to that man," Seneca reports him saying, "to whom I seem mute" (ego istum auditurus non sum, cui mutus videor). Cicero may have been silenced, but Pollio would still find moments to shine, in the centumviral court, for instance; his type of eloquentia had its merits. ${ }^{67}$

Still, the incident allows us to see Pollio's accusations against the dead Cicero in the published version of the Pro Lamia in an additional light. In large part, the orator wished to blacken the memory of his great predecessor. But he was also anxiously suggesting that had Cicero lived, and had he wished to keep living, something like the Philippics would never again be possible. It was a comment on the times in which all men of eloquence found themselves living. ${ }^{68}$

GEORGETOWN UNIVERSITY

e-mail: jo39@georgetown.edu

${ }^{65}$ Following Courtney, I prefer to take aevi decus as 'glorious age' (literally 'glory consisting of an age'). To do so gives more point to the una dies formula. Dahlmann 1975, 95-97 argues that the phrase should refer to Cicero (i.e., the 'glory of his age').

${ }^{66}$ On Severus see Dahlmann 1975, esp. 74-119 and Courtney 1993, 320-28.

${ }^{67}$ For Pollio in the centumviral court, see n. 44 above. Morgan 2000 argues that some of Pollio's other activities-such as writing a history of the civil wars in which he himself appeared as a key witness to events-provided ways for Pollio to maintain a certain independence.

${ }^{68}$ I would like to thank the journal's editor and anonymous readers for the very significant help they gave me with this article. 


\section{BIBLIOGRAPHY}

André, Jacques. 1949. La vie et l'oeuvre de C. Asinius Pollion. Paris: Librairie C. Klincksieck.

Austin, R. G. 1960. M. Tulli Ciceronis Pro M. Caelio Oratio. 3d ed. Oxford: Clarendon Press.

Bauman, Richard A. 1985. Lawyers in Roman Transitional Politics: A Study of the Roman Jurists in Their Political Setting in the Late Republic and Triumvirate. Munich: Beck.

Broughton, T. Robert S. 1951/52. The Magistrates of the Roman Republic. 2 vols. New York: American Philological Association.

Buchheim, Hans. 1960. Die Orientpolitik des Triumvirn M. Antonius: ihre Voraussetzungen, Entwicklung und Zusammenhang mit den politischen Ereignissen in Italien. AHAW 3. Heidelberg: C. Beck.

Buraselis, Kostas. 2000. Kos Between Hellenism and Rome. Transactions of the American Philosophical Society; v. 90, pt. 4. Philadelphia, Pa.: American Philosophical Association.

Courtney, Edward. 1993. The Fragmentary Latin Poets. Oxford: Clarendon Press.

Crawford, M. H. 1996. Roman Statutes. BICS Supp. No. 64. London: Institute of Classical Studies.

Dahlmann, Hellfried. 1975. Cornelius Severus. Mainz: Akademie der Wissenschaften und der Literatur.

DuQuesnay, I. M. Le M. 1984. "Horace and Maecenas: The Propaganda Value of Sermones I." In Poetry and Politics in the Age of Augustus, ed. Tony Woodman and David West, 19-58. Cambridge: Cambridge University Press.

Durry, Marcel. 1950. Eloge funèbre d'une matrone romaine (éloge dit de Turia). Paris: Les Belles Lettres.

Fadinger, Volker. 1969. Die Begründung des Prinzipats; quellenkritische und staatsrechtliche Untersuchungen zu Cassius Dio und der Parallelüberlieferung. Berlin: R. Habelt.

Freudenburg, Kirk. 1993. The Walking Muse: Horace on the Theory of Satire. Princeton, N.J.: Princeton University Press.

- 2001. Satires of Rome: Threatening Poses from Lucilius to Juvenal. Cambridge: Cambridge University Press.

Gabba, Emilio. 1956. Appiano e la storia delle guerre civili. Florence: la Nuova Italia.

1970. Appiani Bellorum civilium liber quintus. Florence: la Nuova Italia.

Gowers, Emily. 2005. "The Restless Companion: Horace, Satires 1 and 2." In The Cambridge Companion to Roman Satire, ed. Kirk Freudenburg, 48-61. Cambridge: Cambridge University Press.

Gowing, Alain. 1992a. The Triumviral Narratives of Appian and Cassius Dio. Ann Arbor: University of Michigan Press. 
1992b. "Lepidus, the Proscriptions, and the Laudatio Turiae." Historia 41:283-96.

Haller, Bertram. 1967. C. Asinius Pollio als Politiker und zeitkritischer Historiker. Münster: Westfälischen Wilhems-Universität.

Hammer, Jacob. 1925. Prolegomena to an Edition of the Panegyricus Messalae. New York: Columbia University Press.

Kaster, Robert A. 1998. "Becoming 'CICERO.'” In Style and Tradition: Studies in Honor of Wendell Clausen, ed. Peter Knox and Clive Foss, 248-63. Stuttgart: Teubner.

Kennedy, George. 1972. The Art of Rhetoric in the Roman World 300 B.C.-A.D. 300. Princeton, N.J.: Princeton University Press.

Leisner-Jensen, Mogens. 1997. "P. Ventidius and Sallust." C\&M 48:325-46.

Levene, D. S. 1997. "God and Man in the Classical Latin Panegyric." PCPS 43:66-103.

Malcovati, Enrica. 1976/79. Oratorum Romanorum Fragmenta liberae rei publicae. 4th ed. 2 vols. Torino: I. B. Paravia.

Millar, Fergus. 1998. The Crowd in Rome in the Late Republic. Ann Arbor: University of Michigan Press.

Morgan, Llewelyn. 2000. “The Autopsy of Asinius Pollio.” JRS 90:51-69.

Morstein-Marx, Robert. 2004. Mass Oratory and Political Power in the Late Roman Republic. Cambridge: Cambridge University Press.

Motzo, R. B. 1940. "Le contiones di M. Antonio e di M. Bruto dopo la morte di Cesare." In Studi di antichità offerti da colleghi e discepoli a Emanuele Ciaceri, 136-43. Genoa: Società anonima editrice Dante Alighieri.

Osgood, Josiah. 2006. Caesar's Legacy: Civil War and the Emergence of the Roman Empire. Cambridge: Cambridge University Press.

Pelling, C. B. R. 1988. Plutarch: Life of Antony. Cambridge: Cambridge University Press.

Peter, Hermann. 1906/14. Historicorum Romanorum Reliquiae. 2 d ed. 2 vols. Leipzig: Teubner.

Reynolds, Joyce. 1982. Aphrodisias and Rome. JRS Monographs No. 1. London: Society for Promotion of Roman Studies.

Richlin, Amy. 1999. “Cicero's Head.” In Constructions of the Classical Body, ed. James I. Porter, 190-211. Ann Arbor: University of Michigan Press.

Roddaz, J.-M. 1988. “Lucius Antonius.” Historia 37:317-46.

Roller, Matthew B. 1997. “Color-blindness: Cicero's Death, Declamation, and the Production of History." CPh 92:109-30.

Sherk, Robert K. 1969. Roman Documents from the Greek East: Senatus Consulta and Epistulae to the Age of Augustus. Baltimore, Md.: Johns Hopkins University Press.

Sordi, Marta. 1985. "La guerra di Perugia e la fonte del 1. V dei Bella Civilia di Appiano." Latomus 44:301-16.

Syme, Ronald. 1939. The Roman Revolution. Oxford: Clarendon Press. . 1964. Sallust. Berkeley and Los Angeles: University of California Press. 
1978. History in Ovid. Oxford: Clarendon Press.

1981. "A Great Orator Mislaid." CQ 31:421-27 = Roman Papers 3.1415-22. 1986. The Augustan Aristocracy. Oxford: Clarendon Press.

Taylor, Lily Ross. 1966. Roman Voting Assemblies: From the Hannibalic War to the Dictatorship of Caesar. Ann Arbor: University of Michigan Press.

Toher, Mark. 2002. "Nepos' Second Edition.” Philologus 146:139-49.

Treggiari, Susan. 1973. "Cicero, Horace, and Mutual Friends: Lamiae and Varrones Murenae." Phoenix 27:245-61.

Wirszubski, Chaim. 1950. Libertas as a Political Ideal at Rome during the Late Republic and Early Principate. Cambridge: Cambridge University Press.

Wiseman, T. P. 1979. Clio's Cosmetics: Three Studies in Greco-Roman Literature. Leicester: Leicester University Press.

Wistrand, Erik. 1976. The So-called Laudatio Turiae: Introduction, Text, Translation, and Commentary. Studia Graeca et Latin Gothoburgensia 34. Lund: Acta Universitatis Gothoburgensis.

Woodman, A. J. 2003. "Poems to Historians: Catullus I and Horace, Odes 2.1." In Myth, History and Culture in Republican Rome: Studies in Honour of T. P. Wiseman, ed. David Braund and Christopher Gill, 191-216. Exeter: Exeter University Press. 